\title{
KEMAMPUAN PENALARAN ADAPTIF MELALUI MODEL RECIPROCAL TEACHING PADA LOGIKA MATEMATIKA DAN HIMPUNAN
}

\author{
Dwi Oktaviana ${ }^{1}$, Rahman Haryadi ${ }^{2}$ \\ Program Studi Pendidikan Matematika, IKIP PGRI Pontianak ${ }^{1,2}$ \\ Email: dwi.oktaviana7@gmail.com ${ }^{1}$
}

\begin{abstract}
Abstrak
Tujuan dalam penelitian ini adalah untuk mengetahui peningkatan kemampuan penalaran adaptif mahasiswa melalui model reciprocal teaching. Penelitian ini merupakan penelitian eksperimen dengan rancangan one group pretest-posttest design. Sampel dalam penelitian ini adalah mahasiswa semester I kelas B IKIP PGRI Pontianak dengan teknik cluster random sampling. Teknik analisis data menggunakan statistik deskriptif dan statistik inferensial dimana untuk menguji apakah terdapat peningkatan kemampuan penalaran adaptif melalui model reciprocal teaching. Hasil penelitian menunjukkan bahwa mahasiswa memperoleh nilai tes awal dengan rata-rata 21,23 sedangkan nilai tes akhir dengan rata-rata 71,36. Setelah menerapkan model reciprocal teaching terhadap kemampuan penalaran adaptif mahasiswa mendapatkan nilai sig. 0,000 dimana sig. $<0,05(\alpha)$. Dengan demikian model reciprocal teaching dapat meningkatkan kemampuan penalaran adaptif mahasiswa.
\end{abstract}

Kata Kunci : Kemampuan Penalaran Adaptif, Reciprocal Teaching, Logika Matematika dan Himpunan

\begin{abstract}
The purpose of this study is to determine the improvement of students' adaptive reasoning abilities through the reciprocal teaching model. This research is experimental research with one group pretest-posttest design. The sample in this study were first semester students of class B IKIP PGRI Pontianak with cluster random sampling technique. The data analysis technique used descriptive statistics and inferential to test whether there was an increase in adaptive reasoning skills through the reciprocal teaching model. The results showed that the students obtained the initial test score with an average of 21,23 while the final test score with an average of 71,36. After applying the reciprocal teaching model to the students' adaptive reasoning ability, they obtained a sig. 0,000 where sig. < $0,05(\alpha)$. Thus the reciprocal teaching model can improve students' adaptive reasoning abilities.
\end{abstract}

Key Words : Adaptive Reasoning Ability, Reciprocal Teaching, Mathematical Logic and Sets

\section{PENDAHULUAN}

Logika Matematika dan Himpunan (LMH) merupakan salah satu mata kuliah wajib yang harus ditempuh mahasiswa IKIP PGRI Pontianak. Adapun cakupan mata kuliah ini adalah membahas tentang logika matematika dan himpunan. Pada cakupan materi logika matematika ini lebih banyak menekankan pada proses penalaran mahasiswa. Logika adalah ilmu untuk berpikir dan menalar dengan benar ([1], [2]). Oleh karena itu, proses penalaran sangat perlu ditingkatkan dalam mata kuliah ini.
Menurut [3] berpendapat bahwa siswa dalam mempelajari matematika memerlukan penalaran untuk mencetuskan ide atau gagasannya dalam memecahkan masalah, sehingga siswa dapat memahami konsep matematika yang benar. Kemampuan bernalar merupakan satu kompetensi yang paling utama dibutuhkan saat sekarang dan di masa depan dalam pembelajaran matematika. Dimana dalam matematika mahasiswa harus dapat memahami penalaran baik induktif, deduktif maupun intuitif. Ketiga penalaran tersebut terdapat di dalam penalaran adaptif [4]. 
Menurut [5] menyatakan bahwa penalaran adaptif menuntut mahasiswa untuk berpikir logis yaitu masuk akal dan menggunakan penalarannya secara benar untuk menyelesaikan suatu permasalahan yang didasarkan pada fakta yang diketahui sebelumnya, dan benar-benar memperhatikan prosedur penyelesaiannya apakah memang sesuai dengan kaidah yang berlaku. Selain itu, [6] menyatakan penalaran adaptif itu sendiri merupakan kapasitas untuk berpikir secara logis tentang hubungan antara konsep dan prosedur yang digeneralisasikan dengan cara masuk akal, sehingga dapat menunjukkan kemungkinan dalam pemecahan masalah, serta dengan cara yang beralasan.

Siswa dikatakan mampu melakukan penalaran adaptif ketika siswa dapat berpikir logis mengenai masalah yang ada, memperkirakan dan merefleksikan masalah dan menjustifikasi prosedur yang digunakan dalam menyelesaikan masalah [7]. Adapun Indikator dalam penalaran adaptif meliputi yaitu: 1) Menyusun dugaan; 2) Memberikan alasan atau bukti terhadap kebenaran suatu pernyataan; 3) Menarik kesimpulan dari suatu pernyataan; 4) Memeriksa kesahihan suatu argument; dan 5) Menemukan pola pada gejala matematis [8].

Namun pada kenyataannya kemampuan penalaran adaptif mahasiswa masih rendah. Berdasarkan pra observasi yang dilakukan peneliti dengan memberikan tes penalaran adaptif kepada 27 mahasiswa diperoleh informasi bahwa terdapat 17 mahasiswa masih mengalami kesulitan dalam menyelesaikan soal penalaran adaptif. Dengan demikian hanya 37,04\% mahasiswa yang mampu menyelesaikan soal penalaran adaptif tersebut. Hal ini didukung oleh penelitian yang dilakukan [9] menyimpulkan bahwa kemampuan penalaran adaptif siswa masih dalam kategori rendah hingga sangat rendah karena terdapat 25 siswa $(69,45 \%)$ hanya mampu berada pada kategori rendah dengan rentangan skor 8-16 (dari skor maksimum 26). Oleh karena itu, penalaran adaptif mahasiswa tersebut sangat perlu ditingkatkan agar tujuan pembelajaran yang diharapkan dapat tercapai dan membuat pembelajaran matematika lebih bermakna. Kemampuan penalaran adaptif tersebut dapat ditingkatkan melalui penerapan model pembelajaran, salah satunya model reciprocal teaching.

Menurut Suparni [10] menyatakan bahwa pengajaran reciprocal teaching ini menjadikan peserta didik lebih aktif dan kreatif dalam menemukan gagasan baru dalam menyelesaikan permasalahan matematika melalui kegiatan belajar mengajar. Reciprocal teaching memiliki empat komponen penting dalam pembelajaran antara lain: mengklarifikasi, memprediksi jawaban, membuat pertanyaan, dan merangkum ([11], [12]). Keempat komponen tersebut dapat menfasilitasi tercapainya indikator dari penalaran adaptif.

Terdapat beberapa penelitian terkait peningkatan kemampuan penalaran adaptif melalui model pembelajaran di antaranya (1) penelitian [4] dan [13] yang menyatakan bahwa model Creative Problem Solving dapat meningkatkan kemampuan penalaran adaptif; penelitian [14] yang menunjukkan bahwa pembelajaran dengan penerapan model PGSD (Problem Guided Solving Discovery) mengalami peningkatan pada kemampuan penalaran adaptif siswa; dan (3) penelitian [15] yang menyatakan bahwa peningkatan kemampuan penalaran adaptif siswa melalui model pembelajaran discovery learning lebih baik daripada menggunakan metode pembelajaran konvensional. Berbeda dari penelitian sebelumnya, dimana peningkatan 
kemampuan penalaran adaptif dilakukan pada model yang berbeda yaitu dengan menggunakan model reciprocal teaching.

Selain itu, terdapat beberapa penelitian model reciprocal teaching dalam meningkatkan kemampuan penalaran matematis di antaranya: (1) Penelitian [16] menyatakan bahwa reciprocal teaching dapat meningkatkan kemampuan penalaran matematis peserta didik; (2) Penelitian [17] juga menyatakan bahwa kemampuan penalaran matematis pada mahasiswa dalam pembelajaran model reciprocal teaching lebih baik dibandingkan pembelajaran konvensional. Berdasarkan analisis tersebut, model pembelajaran reciprocal teaching dirasakan dapat meningkatkan kemampuan penalaran adaptif mahasiswa.

Dengan model reciprocal teaching, mahasiswa dilatih untuk dapat membangun pemahaman yang dimilikinya dalam memecahkan permasalahan matematika dimana mahasiswa dituntut untuk dapat meringkas, menjelaskan, membuat pertanyaaan serta memprediksi dari materi yang diberikan kemudian siswa bergiliran memimpin diskusi untuk menjelaskan kepada temannya, sehingga membuat mahasiswa dapat memahami suatu materi dengan baik. Berdasarkan uraian yang telah dipaparkan sebelumnya, peneliti bertujuan untuk mengetahui peningkatan kemampuan penalaran adaptif mahasiswa melalui model reciprocal teaching pada mata kuliah LMH.

\section{METODE}

Penelitian ini merupakan penelitian eksperimen dengan rancangan one group pretest-posttest design. Di dalam rancangan ini diberikan tes sebanyak dua kali yaitu tes awal yaitu tes sebelum diberikan perlakukan model reciprocal teaching dan tes akhir yaitu tes yang diberikan setelah diterapkan model reciprocal teaching.

Penelitian ini dilakukan di IKIP PGRI Pontianak. Populasi dalam penelitian ini adalah semua mahasiswa semester I IKIP PGRI Pontianak yang terdiri atas 4 kelas yaitu kelas A, B, C, dan D. Sampel penelitian diambil dengan teknik cluster random sampling. Sebelum dilakukan pengambilan sampel dilakukan terlebih dahulu uji homogenitas untuk mengetahui apakah populasi memiliki variansi yang homogen. Jika homogen maka dilanjutkan pengambilan sampel dengan teknik cluster random sampling dimana dilakukan dengan cara pengundian dengan mengundi salah satu kelas yang keluar yang menjadi sampel penelitian. Namun jika populasi tidak homogen, pengambilan sampel dilakukan dengan teknik purposive sampling dengan cara meminta rekomendasi dari dosen pengampu mata kuliah LMH untuk menentukan kelas yang menjadi sampel penelitian. Setelah dilakukan perhitungan terkait uji homogenitas diperoleh hasil bahwa populasi memiliki varians yang homogen sehingga peneliti melakukan pengundian dan hasil yang keluar adalah kelas B yang menjadi sampel dalam penelitian ini.

Teknik pengumpulan data yang digunakan dalam penelitian ini adalah teknik pengukuran dimana instrumen pengumpulan data adalah instrumen tes kemampuan penalaran adaptif yang memuat dengan lima indikator dari penalaran adaptif. Sebelum diberikan ke mahasiswa, soal tes kemampuan penalaran adaptif divalidasi kepada dua orang validator dari dosen program studi pendidikan matematika IKIP PGRI Pontianak terlebih dahulu dengan kriteria valid baru setelah itu diberikan kepada mahasiswa.

Teknik analisis data menggunakan statistik deskriptif untuk menyatakan kemampuan 
penalaran adaptif sebelum dan sesudah diterapkan model reciprocal teaching sedangkan untuk mengetahui apakah terdapat peningkatan kemampuan penalaran adaptif mahasiswa melalui model reciprocal teaching dianalisis menggunakan statistik inferensial dan pengujiannya dilakukan dengan menggunakan SPSS dimana sebelumnya dilakukan uji prasyarat normalitas terlebih dahulu. Jika data berdistribusi normal maka dilanjutkan dengan uji hipotesis menggunakan uji $t$ dan jika data tidak berdistribusi normal maka dilanjutkan dengan uji Wilcoxon.

\section{HASIL DAN PEMBAHASAN}

Data kemampuan penalaran adaptif mahasiswa diperoleh melalui tes awal dan tes akhir. Berikut ini disajikan deskripsi nilai tes awal dan nilai tes akhir pada tabel 1 berikut.

Tabel 1. Statistik Deskriptif Kmampuan Penalaran Adaptif

\begin{tabular}{lrrrrr}
\hline & $N$ & \multicolumn{1}{c}{ Minimum } & Maximum & Mean & Std. Deviation \\
\hline Nilai Tes Awal & 27 & .00 & 40.00 & 21.2344 & 12.27061 \\
Nilai Tes Akhir & 27 & 53.33 & 93.33 & 71.3580 & 11.21885 \\
Valid N (listwise) & 27 & & & & \\
\hline
\end{tabular}

Berdasarkan Tabel 1 terlihat bahwa ratarata kemampuan penalaran adaptif mahasiswa mengalami peningkatan. Hal ini menunjukkan bahwa model reciprocal teaching memberikan pengaruh terhadap kemampuan penalaran adaptif mahasiswa. Namun apakah benar peningkatan kemampuan penalaran adaptif mahasiswa tercapai melalui model reciprocal teaching perlu dilakukan uji statistik lanjutan.
Kemudian dilakukan pengujian hipotesis untuk mengetahui apakah terdapat peningkatan kemampuan penalaran adaptif mahasiswa setelah diterapkan model reciprocal teaching. Sebelumnya dilakukan perhitungan pengujian normalitas terhadap data kemampuan penalaran adaptif mahasiswa sebelum dan setelah dimana dapat dilihat pada Tabel 2 berikut.

Tabel 2. Ringkasan Hasil Uji Normalitas

\begin{tabular}{lcccccr}
\hline & \multicolumn{2}{c}{ Kolmogorov-Smirnov $^{a}$} & \multicolumn{3}{c}{ Shapiro-Wilk } \\
& Statistic & $d f$ & \multicolumn{1}{c}{ Sig. } & Statistic & df & \multicolumn{1}{c}{ Sig. } \\
\hline Nilai Tes Awal & .153 & 27 & .108 & .930 & 27 & .069 \\
Nilai Tes Akhir & .218 & 27 & .002 & .929 & 27 & .065 \\
\hline
\end{tabular}

Berdasarkan Tabel 2 diketahui bahwa nilai Sig. pada Shapiro-Wilk sebesar 0,069 dan 0,065 dimana lebih besar dari 0,05. Maka sesuai dengan dasar pengambilan keputusan dalam uji normalitas ShapiroWilk tersebut, dapat disimpulkan bahwa data berdistribusi normal. Dengan demikian, asumsi atau persyaratan normalitas dalam uji- $t$ sudah terpenuhi. Selanjutnya dilakukan uji hipotesis dapat dilihat pada Tabel 3 berikut.

Tabel 3. Ringkasan Hasil Uji Hipotesis

\begin{tabular}{|c|c|c|c|c|c|c|c|c|c|}
\hline & \multicolumn{9}{|c|}{ Paired Differences } \\
\hline & & \multirow[b]{4}{*}{ Mean } & \multirow{2}{*}{\multicolumn{7}{|c|}{$\begin{array}{l}95 \% \text { Confidence } \\
\text { Interval of the }\end{array}$}} \\
\hline & & & & & & & & & \\
\hline & & & Std. & Std. Error & Diffe & ence & & & Sig. (2- \\
\hline & & & Deviation & Mean & Lower & Upper & $t$ & $d f$ & tailed) \\
\hline Pair 1 & $\begin{array}{l}\text { Nilai Tes Awal - } \\
\text { Nilai Tes Akhir }\end{array}$ & -50.12358 & 7.00930 & 1.34894 & -52.89637 & -47.35079 & -37.158 & 26 & .000 \\
\hline
\end{tabular}


Berdasarkan Tabel 3 diperoleh nilai Sig. (2tailed) uji $t$ Paired adalah 0,000 lebih kecil dari 0,05 yang artinya terdapat peningkatan yang signifikan antara nilai tes awal dan nilai tes akhir yang telah diberikan.

Hasil penelitian menunjukkan bahwa terdapat peningkatan kemampuan penalaran adaptif mahasiswa melalui model reciprocal teaching. Hal ini terjadi karena model reciprocal teaching mendorong mahasiswa untuk mampu memahami mandiri pada materi logika matematika, sehingga menuntut mahasiswa untuk selalu aktif dalam pembelajaran.

Selain itu, pada pembelajaran reciprocal teaching memacu mahasiswa untuk berperan menjadi seorang guru dimana untuk menyampaikan informasi kepada teman-temannya maka setiap mahasiswa selalu berinisiatif untuk mengasah pengetahuan yang dimilikinya secara mandiri tanpa bergantung kepada teman lainnya. Pada penjelasan sebelumnya, empat komponen pembelajaran reciprocal teaching juga berperan dalam meningkatkan kemampuan penalaran adaptif mahasiswa yaitu pada merangkum, di sini mahasiswa dituntut untuk membuat konsep materi yang akan disampaikan kepada teman lainnya ketika mahasiswa tersebut berperan sebagai guru, sehingga mengharuskan mahasiswa dapat bernalar dan membangun pengetahuannya sendiri dalam memahami materi logika matematika. Selanjutnya pada komponen membuat pertanyaan, mahasiswa dituntut untuk meningkatkan rasa keingintahuan mahasiswa dalam memahami materi logika matematika sehingga mahasiswa selalu bernalar dalam proses pembelajaran.

Pada komponen menjelaskan, mahasiswa dituntut untuk dapat mengembangkan kemampuan penalaran adaptif yang dimilikinya dalam menjelaskan materi logika matematika sehingga mahasiswa terbiasa dalam melakukan penalaran. Sedangkan pada komponen memprediksi, mahasiswa dituntut untuk dapat menentukan ide-ide penting dalam materi logika matematika. Dimana pada materi tersebut selalu ditekankan proses penalaran sehingga mahasiswa sudah terlatih dalam melakukan penalaran adaptif. Keempat komponen pembelajaran reciprocal teaching tersebut mengharuskan mahasiswa untuk dapat mengkonstruksi sendiri pengetahuannya. Hal ini sejalan dengan kelebihan model reciprocal teaching yaitu melatih kemampuan siswa belajar mandiri sehingga siswa dalam belajar mandiri dapat ditingkatkan, melatih siswa untuk menjelaskan kembali materi yang dipelajari kepada pihak lain dengan demikian melatih siswa tampil di depan umum, orientasi pembelajaran adalah investigasi dan penemuan yang pada dasarnya adalah pemecahan masalah dengan demikian kemampuan bernalar siswa juga semakin berkembang, dan mempertinggi kemampuan siswa dalam memecahkan masalah [18]. Dengan demikian, model reciprocal teaching dapat meningkatkan kemampuan penalaran adaptif mahasiswa. Hal ini sejalan dengan penelitian yang dilakukan oleh [19] menyimpulkan bahwa terdapat pengaruh yang signifikan pada hasil belajar matematika antara siswa yang diajar dengan menggunakan model reciprocal teaching dan siswa yang diajar dengan tidak menggunakan model reciprocal teaching. Selaras juga dengan penelitian yang dilakukan [16] menyimpulkan bahwa kemampuan penalaran matematis peserta didik yang dilihat dari hasil tes setelah dilakukan pembelajaran dengan model reciprocal teaching dikategorikan cukup dengan rata-rata sebesar 67,89.

\section{SIMPULAN}

Berdasarkan hasil penelitian dan pembahasan dapat disimpulkan bahwa terdapat peningkatan kemampuan 
penalaran adaptif mahasiswa melalui model reciprocal teaching. Selain itu, model reciprocal teaching memberikan pengaruh positif dalam meningkatkan kemampuan penalaran adaptif mahasiswa pada mata kuliah logika matematika dan himpunan.

\section{UCAPAN TERIMA KASIH}

Terima kasih diucapkan kepada KEMENRISTEKDIKTI dana hibah Penelitian Dosen Pemula tahun anggaran 2019 yang diberikan serta IKIP PGRI Pontianak sebagai mitra dalam kegiatan penelitian.

\section{DAFTAR PUSTAKA}

[1] D. E. Novianti. "Analisis Kesalahan dalam Mengerjakan Soal Materi Logika Matematika Mahasiswa Prodi Pendidikan Matematika IKIP PGRI Bojonegoro". Jurnal Pendidik. dan Pembelajaran Matematika, vol. 1, no. 1, pp. 24-30, 2015.

[2] M. Mutia. "Analisis Kesalahan Mahasiswa dalam Menyelesaikan Soal Negasi Pernyataan Majemuk pada Logika Matematika”. Numerical: Jurnal Matematika dan Pendidikan Matematika, vol. 1, no. 1, pp. 35-44, 2017.

[3] M. Bernard. "Meningkatkan Kemampuan Komunikasi dan Penalaran Serta Disposisi Matematik Siswa SMK dengan Pendekatan Kontekstual Melalui Game Adobe Flash CS 4.0". Infinity, vol. 4, no. 2, pp. 197-222, 2015.

[4] D. Nopitasari. "Pengaruh Model Pembelajaran Creative Problem Solving (Cps) terhadap Kemampuan Penalaran Adaptif Matematis Siswa". Mathline: Jurnal Matematika dan Pendidikan Matematika, vol. 1, no. 2, pp. 103112, 2016.

[5] G. Harel. "Deductive Reasoning in Mathematics

Education".
Encyclopedia of Mathematics Education, pp. 143-147, 2014.

[6] D. A. Reid. "Abductive Reasoning in Mathematics Education: Approaches to and Theorisations of a Complex Idea". Eurasia Journal Mathematics, Science, and Technology Education, vol. 14, no. 9, pp. 1-13, 2018.

[7] A. O. A. Awofala. "Assessing Senior Secondary School Students' Mathematical Proficiency as Related to Gender and Performance in Mathematics in Nigeria". International Journal of Research in Education and Science, vol. 3, no. 2, pp. 488-502, 2017.

[8] D. B. Widjajanti. "Mengembangkan Kecakapan Matematis Mahasiswa Calon Guru Matematika melalui Strategi Perkuliahan Kolaboratif Berbasis Masalah". Prosiding Seminar Nasional Penelitian, Pendidikan dan Penerapan MIPA, pp. 151-158, 2011.

[9] T. Indriani, A. Hartoyo, dan D. Astuti. "Kemampuan Penalaran Adaptif Siswa dalam Memecahkan Masalah Kelas VIII SMP Pontianak". Jurnal Pendidik. dan Pembelajaran Khatulistiwa, vol. 6, no. 2, pp. 1-12, 2017.

[10] Suparni. "Model Pembelajaran Reciprocal Teaching Kaitannya dengan Kemampuan Komunikasi Matematika Siswa". Logaritma, vol. 4, no. 1, pp. 110-124, 2016.

[11] D. E. Prisiani, R. Wahab, dan A. D. Putri. "Pengaruh Pendekatan Reciprocal Teaching terhadap Kemampuan Pemahaman Konsep pada Pembelajaran Matematika di Kelas X SMA Muhammadiyah 2 Palembang". Jurnal Pendidikan Matematika RAFA, vol. 2, no. 2, pp. 214-228, 2016.

[12] Muslimin, Indaryanti, dan E. Susanti. "Pembelajaran Matematika dengan Model Reciprocal Teaching untuk 
Melatih Kecakapan Akademik Siswa di Kelas VIII SMP”. Jurnal Pendidikan Matematika, vol. 11, no. 1, pp. 1-14, 2017.

[13] A. Muin, S. H. Hanifah, and F. Diwidian. "The Effect of Creative Problem Solving on Students' Mathematical Adaptive Reasoning". Journal of Physics: Conference Series, vol. 948, pp. 1-6, 2018.

[14] Magfirah, A. M. I. T. Asfar, A. M. I. A. Asfar, A. Fauziah, dan Sumiati. "Penerapan Model Pembelajaran PGSD (Problem Guided Solving Discovery) dalam Meningkatkan Kemampuan Penalaran Adaptif Siswa". Prosiding Seminar Nasional Penelitian \& Pengabdian Kepada Masyarakat, pp. 381-385, 2019.

[15] M. Arifudin, H. Wilujeng, dan R. B. Utomo. "Pengaruh Metode Discovery Learning pada Materi Trigonometri terhadap Kemampuan Penalaran Adaptif Siswa SMA". KALAMATIKA, vol. 1, no. 2, pp. 129-140, 2016.

[16] T. Andira, B. Santoso, dan M. Yusup. "Penerapan Model Pembelajaran Reciprocal Teaching Ditinjau dari Kemampuan Penalaran Matematis Peserta Didik pada materi Bangun Datar Segiempat”. Pythagoras: Jurnal Pendidikan Matematika, vol. 13, no. 1, pp. 8898, 2018.

[17] M. Firdaus, Y. Darma, dan R. Haryadi. "Kemampuan Penalaran Matematis dan Motivasi Mahasiswa Calon Guru Melalui Model Reciprocal Teaching”. Edukasi Matematika dan Sains, vol. 2, no. 1, pp. 1-12, 2014.

[18] Noorliani dan E. Kusumawati. "Pengaruh Model Reciprocal Teaching terhadap Hasil Belajar Matematika Siswa Kelas VIII SMP”. EDU-MAT Jurnal Pendidikan Matematika, vol. 1, no. 1, pp. 34-41,
2013.

[19] R. Awaliah dan R. Idris. "Pengaruh Penggunaan Model Reciprocal Teaching terhadap Hasil Belajar Matematika Siswa Kelas VIII MTSN Balang-Balang Kecamatan Bontomarannu Kabupaten Gowa". MaPan: Jurnal Matematika dan Pembelajaran, vol. 3, no. 1, pp. 5972, 2015. 